\title{
THE MANAGEMENT OF INFECTION AFTER KÜNTSCHER NAILING OF THE FEMUR
}

\author{
J. N. Wilson, London, ENGLAND \\ From the Institute of Orthopaedics, London
}

Despite the increased use of intramedullary fixation in fractures of the femur, review of the literature reveals little information on the management of bone infection. This may be because it seldom occurs. MacAusland and Eaton (1963) reported fourteen patients from Boston: in spite of treatment, four wounds remained unhealed and one patient's leg had to be amputated. No fixed method of treatment had been adopted or was advised, but it was stressed that the nail should be retained until the fracture was consolidated, despite the presence of sepsis. Weber and Hirtzman (1964) reported thirty-five cases with an amputation rate of 29 per cent and residual sinuses in 20 per cent. Apart from drainage of abscesses, non-operative treatment was advised until the fracture was united. The nail was then removed and the fracture site treated by saucerisation and muscle graft. The average time of treatment was more than thirty months.

The aim of the present paper is to outline the steps in diagnosis, investigation and treatment which have proved successful in the management of seven cases in which the nail was removed early.

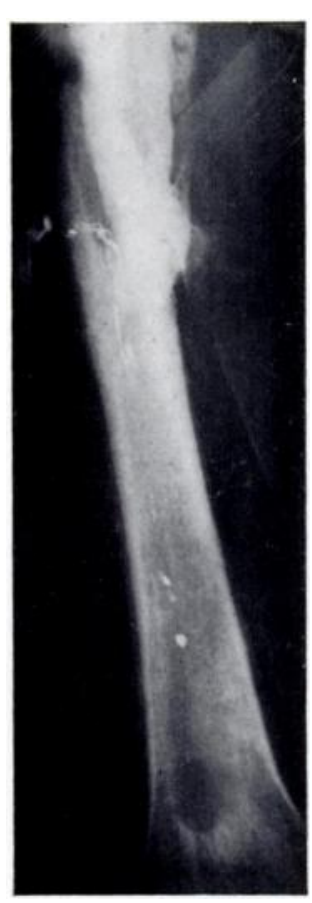

FIG. 1

\section{MATERIAL}

This consists of six cases treated personally and one other case. In every case the nailing had been done by a different surgeon. Table I shows the clinical features. The time of fracture to final healing varied from nine months to two and a half years. The pattern of treatment used was based on the experience gained from the first case. The main feature has been early exposure of the lower end of the nail or nail track, allowing dependent drainage, and antibiotic irrigation of the previously closed end. Figure 1 shows the sinograph in the first case. It shows a pocket of infection at the lower end of the nail track fourteen months after nailing and about nine months after removal of the nail. Despite repeated drainage of the fracture site the wound did not heal. Six weeks after draining the pocket at the lower end of the track all the sinuses were closed.

Localised infection developing at the lower end of the nail track has been observed before (Böhler 1948, Brav and Jeffress 1953), but no indication has been given of its significance in treatment.

FIG. 1

Case 1-Sinograph showing rarefaction around the lower end of the nail track nine months after removal of the nail (fourteen months after fracture) showing opaque fluid extending to the bottom of the nail track.

\section{DIAGNOSIS}

Radiological studies of the cases have revealed a fairly constant sign of sepsis which I have not read about elsewhere. This is a periosteal reaction along the shaft of the bone as far as the lower end of the nail track. It appears to occur mainly in the lower fragment and has been seen in four cases of the series, becoming evident about three months after operation. Trueta and 
TABLE I

The Clinical Course of Seven Cases

\begin{tabular}{|c|c|c|c|c|c|c|c|c|c|}
\hline $\begin{array}{c}\text { Case } \\
\text { number }\end{array}$ & $\begin{array}{c}\text { Side } \\
\text { affected }\end{array}$ & Sex & $\begin{array}{l}\text { Age } \\
\text { (years) }\end{array}$ & $\begin{array}{c}\text { Date of } \\
\text { accident } \\
\text { and progress }\end{array}$ & $\begin{array}{c}\text { First } \\
\text { operation }\end{array}$ & Infection & $\begin{array}{l}\text { Secondary } \\
\text { operations } \\
\text { and other } \\
\text { treatment }\end{array}$ & $\begin{array}{c}\text { Removal } \\
\text { of nail }\end{array}$ & Comments \\
\hline 1 & $\begin{array}{l}\text { Right } \\
\text { femur }\end{array}$ & $\mathbf{M}$ & 34 & $\begin{array}{c}\text { May } 1957 . \\
\text { Comminuted. } \\
\text { Difficult } \\
\text { pinning }\end{array}$ & $\begin{array}{l}2 \text { days } \\
\text { later }\end{array}$ & $\begin{array}{l}3 \text { weeks } \\
\text { after } \\
\text { operation }\end{array}$ & 8 & 7 months & $\begin{array}{l}\text { Fracture united } \\
1 \frac{1}{2} \text { years. } \\
\text { Occasional } \\
\text { discharge }\end{array}$ \\
\hline 2 & $\begin{array}{l}\text { Left } \\
\text { femur }\end{array}$ & $\mathbf{M}$ & 28 & $\begin{array}{c}\text { August } 1961 . \\
\text { Refracture } \\
\text { February } 1962\end{array}$ & $\begin{array}{c}\text { February } \\
1962\end{array}$ & $\begin{array}{c}1 \text { month } \\
\text { after } \\
\text { operation }\end{array}$ & 4 & 6 months & $\begin{array}{l}\text { Clinically united } \\
\text { at } 6 \text { months. } \\
\text { Radiologically } \\
\text { sound } 1 \text { year. } \\
\text { Healed }\end{array}$ \\
\hline 3 & $\begin{array}{l}\text { Right } \\
\text { femur }\end{array}$ & $\mathbf{M}$ & 28 & $\begin{array}{l}\text { 1958. No details } \\
\text { except pin } \\
\text { protruded in } \\
\text { buttock }\end{array}$ & 1958 & $\begin{array}{c}2-4 \text { weeks } \\
\text { after } \\
\text { operation }\end{array}$ & $\begin{array}{c}\text { Unknown } \\
\text { number }\end{array}$ & 2 years & $\begin{array}{l}\text { All sinuses healed. } \\
\text { Fracture united }\end{array}$ \\
\hline 4 & $\begin{array}{l}\text { Right } \\
\text { femur }\end{array}$ & $\mathbf{M}$ & 29 & $\begin{array}{l}\text { April 1961. } \\
\text { Comminuted } \\
\text { fracture upper } \\
\text { third. Difficult } \\
\text { operation }\end{array}$ & $\begin{array}{l}2 \text { weeks } \\
\text { later }\end{array}$ & $\begin{array}{c}1 \text { week } \\
\text { after } \\
\text { operation }\end{array}$ & 3 & 8 months & $\begin{array}{l}\text { All sinuses healed. } \\
\text { Fracture not } \\
\text { radiologically } \\
\text { solid. } \\
\text { Clinically united }\end{array}$ \\
\hline 5 & $\begin{array}{l}\text { Right } \\
\text { femur }\end{array}$ & $\mathbf{M}$ & 36 & $\begin{array}{l}\text { May } 1959 . \\
\text { Compound } \\
\text { fracture mid } \\
\text { third with } \\
\text { fractured patella }\end{array}$ & $\begin{array}{c}\text { The same } \\
\text { day }\end{array}$ & $\begin{array}{c}1 \text { week } \\
\text { after } \\
\text { operation }\end{array}$ & $\begin{array}{l}\text { Treated } \\
\text { by } \\
\text { prolonged } \\
\text { antibiotics }\end{array}$ & 11 years & $\begin{array}{c}\text { Fracture united } \\
1 \text { year. Clinically } \\
\text { and radiologically } \\
\text { infected. No } \\
\text { discharge. Healed }\end{array}$ \\
\hline 6 & 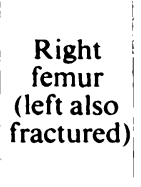 & F & 27 & $\begin{array}{l}\text { July } 1963 . \\
\text { Comminuted } \\
\text { fracture } \\
\text { upper third. } \\
\text { Complicated } \\
\text { nailing }\end{array}$ & $\begin{array}{l}12 \text { days } \\
\text { later }\end{array}$ & $\begin{array}{c}2 \text { weeks } \\
\text { after } \\
\text { operation }\end{array}$ & 2 & 6 months & $\begin{array}{c}\text { Fracture } \\
\text { radiologically } \\
\text { united } 5 \text { months. } \\
\text { Healed }\end{array}$ \\
\hline 7 & $\begin{array}{l}\text { Right } \\
\text { femur }\end{array}$ & $\mathbf{M}$ & 18 & $\begin{array}{l}\text { September } 1957 . \\
\text { Comminuted } \\
\text { fracture } \\
\text { mid third } \\
\text { of femur. } \\
\text { Difficult } \\
\text { nailing }\end{array}$ & $\begin{array}{l}8 \text { days } \\
\text { later }\end{array}$ & $\begin{array}{c}1 \text { week } \\
\text { after } \\
\text { operation }\end{array}$ & 6 & 5 months & \begin{tabular}{|c|} 
Fracture \\
radiologically \\
solid 9 months \\
after operation. \\
Wound healed but \\
radiographs show \\
sequestra at \\
fracture site \\
(encysted)
\end{tabular} \\
\hline
\end{tabular}

Cavadias (1955) attributed periosteal reaction of the shaft after nailing to vascular disorganisation. They suggested that the nail damaged the nutrient artery. A similar periosteal reaction was recorded by Rush, Fitts, Gibbons and Monroe (1952) in the experimental nailing of infected fractures. Whatever the explanation of the reaction it seems to indicate that there is infection along the whole of the nail track.

There are five points in the diagnosis of infection: pyrexia of unknown origin associated with brawny thickening of the affected thigh; tenderness or swelling over either end of the nail; periosteal reaction extending as far as the lower end of the nail; a positive sinograph; and rarefaction at the lower end of the nail track. Tenderness with abscess formation has also been detected over the lower end of the nail. Diagnostic periosteal reaction of the shaft of the lower fragment is shown in Figure 2, and it only extended to the lower end of the nail. A typical sinograph of the fracture area can be seen in Figure 3, which shows the extent of local infection and outlines the sequestra; opaque fluid passes down the nail track, indicating infection at its lower end (Fig. 4). The last point in diagnosis, that of rarefaction

VOL. $48 \mathrm{~B}$, NO. 1, FEBRUARY 1966 
around the lower end of the nail track, is not always present, but if it occurs it may lead to local abscess formation (Fig. 5). Opaque fluid injected for sinography can be seen escaping into the soft tissue on the medial side of the lower end of the nail track. The patient presented with an abscess at this site two years after removal of the nail.

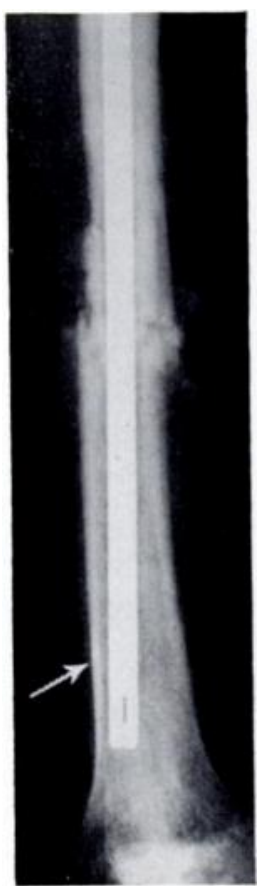

Fig. 2

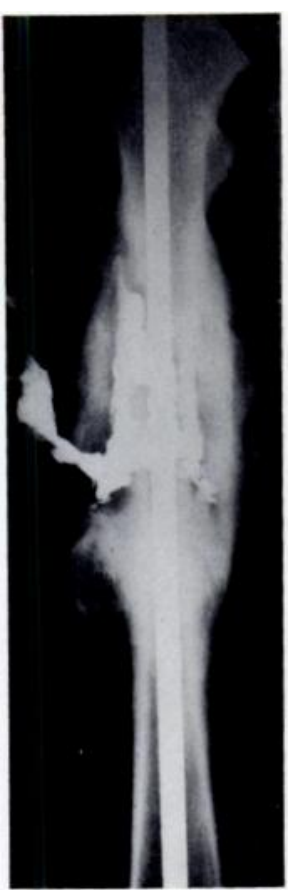

Fig. 3

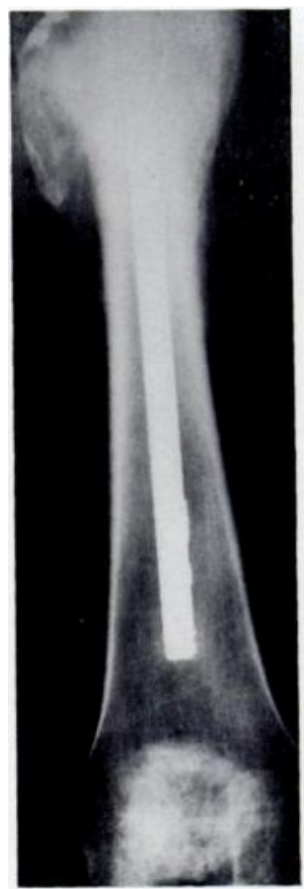

Fig. 4

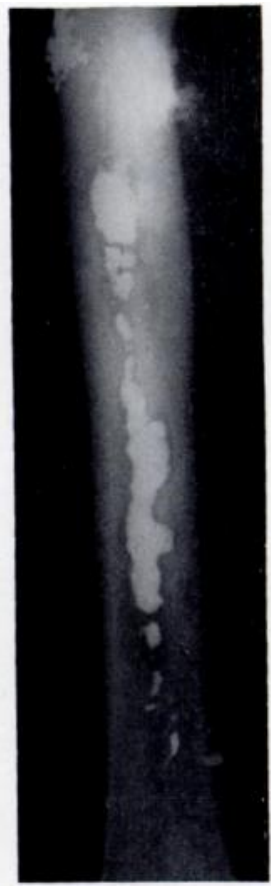

Fig. 5

Figure 2-Radiograph five months after operation showing periosteal reaction along the shaft of femur as far as the end of the nail (Case 5). Figure 3-Typical sinograph in an infected case, showing the extent of the local infection and outlining a sequestrum (Case 6). Figure 4-Sinograph showing that opaque fluid passes down to the bottom end of the nail (Case 6). Figure 5-Sinograph four years after fracture and two years after removal of nail. Marked rarefaction and abscess formation has occurred at the lower end of the femur on the inner side of the nail track (Case 3).

\section{TREATMENT}

A preliminary sinograph is valuable in assessing whether dependent drainage is necessary. In all cases in which this drainage was carried out the sinograph showed fluid passing down the whole length of the nail. It is a particularly useful procedure in determining the extent of infection in the case which presents with the nail already removed.

The first stage of the operative treatment has consisted in exploration of the fracture site; drainage if indicated; and insertion of tubes at both sites of operation for instillation of antibiotics. Preliminary sensitivity tests on the causative organism determine the choice of antibiotic. Two drugs have been used in an attempt to reduce the problem produced by resistive organisms. Local instillation has been used along with parenteral treatment, one dose of both drugs being instilled locally morning and evening. The wound has been opened widely at the fracture site and any sequestra removed. When the nail is left in position it may not be possible to remove all the dead bone at this stage. Further swabs should be taken from the depths of the wound and sent for sensitivity tests, and after insertion of a plastic instillation tube down to the nail this wound has been closed. The tubes used for Redon drainage have been found satisfactory for instillation. The lower end of the nail has then been located under radiographic control, and a hole about three-quarters of an inch in diameter made over it and, after removing any debris, an instillation tube is inserted. 
It has been possible to continue using the tubes for four to six weeks, and in all cases in which the nail was still in position the track has been rendered sterile by that time. The second stage of treatment has then been carried out-removal of the nail and further exploration of the fracture site. In every case more sequestra have been found and removed. At the same time the drainage wound has been reopened and antibiotic tubes reinserted at this site and also at the fracture. The same régime of instillation combined with general antibiotic administration has been continued for some weeks. The indication for the removal of the tubes was when the instillation fluid began to reflux as soon as it was injected.

It is felt that the presence of the nail prevents natural healing of the infection and that it should be removed as soon as possible after sterilisation of the nail track. The time of its removal should not depend upon union of the fracture. On the régime outlined, several months from the time of fracture have always elapsed before the stage for nail removal has been reached and there has been no problem of instability. Simple immobilisation on a Thomas's splint is all that is required. Clearly, if the fracture shows no callus and is therefore assumed to be unstable it would be unwise to remove the nail, but fortunately these fractures appear to produce abundant callus and can be considered stable by the time nail removal is necessary. It will be seen from Table I that no nail was removed earlier than five months after the original operation. On the other hand, although the fractures were stable they were not necessarily

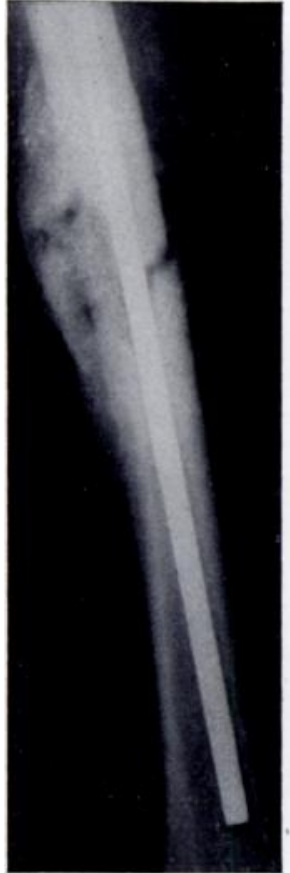

Fig. 6

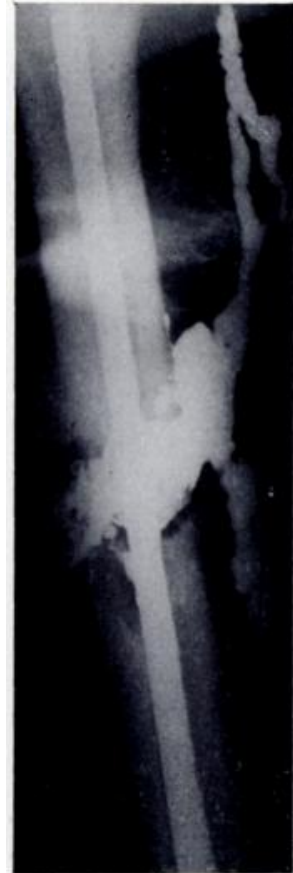

Fig. 7

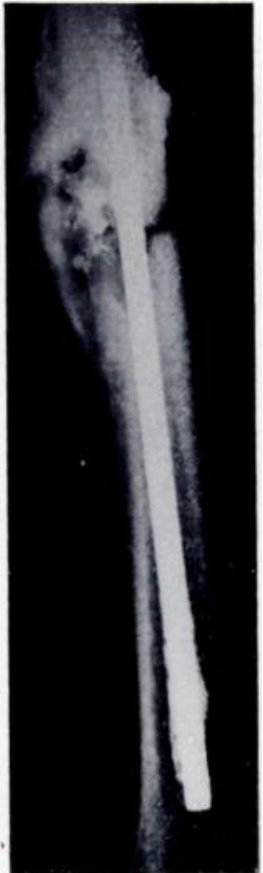

FIG. 8

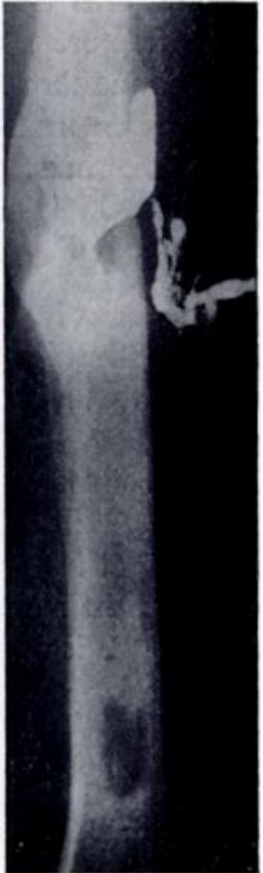

FiG. 9

Case 2. Figure 6-The appearance four months after nailing, illustrating the diagnostic sign of periosteal reaction along the shaft of the femur. Figure 7-Sinograph of the fracture site showing the extensive infection and long sinus track. Figure 8-Radiograph of the lower end of the nail showing that the opaque fluid has passed down the whole length of the track. Figure 9-Sinograph showing that the original nail track has closed.

consolidated at this stage and it is considered to be an unnecessary delay to wait for bony union before removing the nail.

Parenteral antibiotic therapy has been used for three to six months. The operative treatment outlined localises the infection to the original fracture site, reducing the condition to a relatively 
small area of osteomyelitis. As in any osteomyelitic lesion secondary operations may be necessary to deal with recurrence of infection. Late sequestrectomy has been necessary in two cases.

\section{RESULTS}

These are summarised in Table I. For all practical purposes the wounds have remained healed in every case. In the first patient, who works as a civil engineer in Africa, there is an occasional discharge from an area of infection in the greater trochanter. This has not required hospital treatment for seven years. All fractures have united by bone except in Case 4; but even in this patient the fracture is clinically sound and the patient is able to work below ground in a mine. In three cases knee movement has been restricted to a range of about 45 degrees, but in the other four flexion has been restored to beyond the right angle.

An illustrative case (Case 2)-This patient sustained a simple fracture of the left femur, which was treated conservatively, but refractured seven months later. It was nailed, but a month later the wound became infected. Figure 6 shows the condition four months after nailing. It well illustrates periosteal reaction along the shaft of the bone. The sinograph (Fig. 7) demonstrates the extensive infection around the fracture and the long sinus track. Radiographs of the lower end of the nail (Fig. 8) show the full extent of the infection, with rarefaction around the lower end of the nail. Exploration of the sinus with sequestrectomy, sump drainage and antibiotic instillation was carried out four months after refracture. The nail was removed two months later and all the sinuses healed. Three months later further discharge occurred from the fracture site and radiographs showed another sequestrum. Another sinograph (Fig. 9) showed that the original nail track had closed. This illustrates again the value of the sinograph in determining the extent of the infection. Simple sequestrectomy resulted in rapid healing of the sinus. There has been no further breakdown of the wound.

\section{SUMMARY}

1. Seven cases of infection following medullary na:ling of the femur have been studied.

2. Points in the diagnosis of nail track infection are emphasised, especially periosteal reaction.

3. It is felt that a sinograph is an essential part of the investigation and can be useful to assess progress.

4. The principles of treatment of established nail track infection are: adequate drainage of the fracture site; dependent drainage of the whole track by draining the pocket at the lower end; the use of instillation tubes to irrigate the nail track with antibiotics. Once the fracture is stable and the nail track adequately treated by local and general antibiotics the nail should be removed. It is not considered necessary to wait for bony union before removal of the nail.

\section{REFERENCES}

BöHLER, L. (1948): Medullary Nailing of Küntscher, pp. 144-163. London: Baillière, Tindall \& Cox.

Brav, E. A., and Jefrress, V. H. (1953): Modified Intramedullary Nailing in Recent Gunshot Fractures of the Femoral Shaft. Journal of Bone and Joint Surgery, 35-A, 141.

MacAusland, W. R., Jun., and Eaton, R. G. (1963): The Management of Sepsis Following Intramedullary Fixation for Fractures of the Femur. Journal of Bone and Joint Surgery, 45-A, 1643.

Rush, H. L., Jun., Fitrs, W. T., Jun., Gibbons, J., and Monroe, E. W. (1952): Intramedullary Nailing in the Presence of Infection: an Experimental Study in Dogs. Surgery, Gynecology and Obstetrics, 94, 727.

Trueta, J., and Cavadias, A. X. (1955): Vascular Changes Caused by the Küntscher Type of Nailing. Journal of Bone and Joint Surgery, 37-B, 492.

Weber, R., and Hirtzman (1964): Les ostéites du femur après enclouage centro-médullaire. Revue de Chirurgie Orthopédique, 50, 77. 